\title{
Crypt Stem Cell Survival in the Mouse Intestinal Epithelium Is Regulated by Prostaglandins Synthesized through Cyclooxygenase-1
}

\author{
Steven M. Cohn, ${ }^{\star}$ Suzanne Schloemann, ${ }^{\star}$ Teresa Tessner, ${ }^{\star}$ Karen Seibert, ${ }^{\ddagger}$ and William F. Stenson* \\ $*$ Department of Medicine, Washington University School of Medicine, and ${ }^{\ddagger}$ G.D. Searle, St. Louis, Missouri 63110
}

\begin{abstract}
Prostaglandins (PGs) are important mediators of epithelial integrity and function in the gastrointestinal tract. Relatively little is known, however, about the mechanism by which PGs affect stem cells in the intestine during normal epithelial turnover, or during wound repair. PGs are synthesized from arachidonate by either of two cyclooxygenases, cyclooxygenase-1 (Cox-1) or cyclooxygenase-2 (Cox-2), which are present in a wide variety of mamalian cells. Cox-1 is thought to be a constitutively expressed enzyme, and the expression of Cox-2 is inducible by cytokines or other stimuli in a variety of cell types. We investigated the role of PGs in mouse intestinal stem cell survival and proliferation following radiation injury. The number of surviving crypt stem cells was determined $3.5 \mathrm{~d}$ after irradiation by the microcolony assay. Radiation injury induced a dose-dependent decrease in the number of surviving crypts. Indomethacin, an inhibitor of Cox-1 and Cox-2, further reduced the number of surviving crypts in irradiated mice. The indomethacin dose response for inhibition of $\mathrm{PGE}_{2}$ production and reduction of crypt survival were similar. DimethylPGE $\mathrm{F}_{2}$ reversed the indomethacin-induced decrease in crypt survival. Selective Cox-2 inhibitors had no effect on crypt survival. $\mathrm{PGE}_{2}$, Cox-1 mRNA, and Cox-1 protein levels all increase in the $3 \mathrm{~d}$ after irradiation. Immunohistochemistry for Cox-1 demonstrated localization in epithelial cells of the crypt in the unirradiated mouse, and in the regenerating crypt epithelium in the irradiated mouse. We conclude that radiation injury results in increased Cox-1 levels in crypt stem cells and their progeny, and that $\mathrm{PGE}_{2}$ produced through Cox-1 promotes crypt stem cell survival and proliferation. (J. Clin. Invest. 1997. 99:1367-1379.) Key words: epithelium • indomethacin • prostaglandin E2 • wound healing • bromodeoxyuridine
\end{abstract}

\section{Introduction}

The adult intestinal epithelium is continuously and rapidly replaced by cell replication within the crypts of Lieberkühn and subsequent migration of their progeny onto the villus epithelium in the small intestine, or onto the surface epithelium in

Address correspondence to Steven M. Cohn, M.D., Ph.D., Washington University School of Medicine, 660 S. Euclid Avenue, Campus Box 8124, St. Louis, MO 63110. Phone: 314-362-8940; FAX: 314-3628959.

Received for publication 29 January 1996 and accepted in revised form 21 January 1997.

J. Clin. Invest.

(C) The American Society for Clinical Investigation, Inc.

0021-9738/97/03/1367/13 \$2.00

Volume 99, Number 6, March 1997, 1367-1379 the colon (1). Considerable evidence has emerged that prostaglandins can modulate gut epithelial cell proliferation and survival in vitro $(2,3)$. Furthermore, a number of recent studies have suggested that chronic inhibition of prostaglandin synthesis in the colon can cause regression of adenomatous polyps and decrease the incidence of invasive carcinoma $(4,5)$. Relatively little is known, however, about the mechanisms by which prostaglandins may regulate epithelial cell replication, differentiation, and migration during normal turnover of the adult intestinal epithelium or during intestinal wound repair.

Intestinal epithelial cells are ultimately derived from multipotent stem cell(s) located near the base of each intestinal crypt (6-9). In the adult mouse small intestine, these crypt stem cells divide rarely to produce a daughter stem cell (selfrenewal) as well as a more rapidly replicating transit cell. Transit cells in turn undergo a number of rapid cell divisions in the proliferative zone located in the lower half of each crypt. Their progeny subsequently differentiate into the mature epithelial cell types found in the small intestine as the epithelial cells migrate away from the proliferative zone in each intestinal crypt $(6,10,11)$. Crypt stem cells also play a central role in mucosal regeneration following injury (11). Intestinal injury induced by a variety of noxious agents (chemical, physical, infectious, and inflammatory) can result in destruction of the epithelial barrier. After injury, the adjacent epithelial cells initially migrate over the wound to re-form an epithelial monolayer. Subsequent restoration of normal epithelial architecture is a multistep process: $(a)$ stem cells proliferate to increase their numbers and to give rise to the more rapidly proliferating transit cell population; $(b)$ the transit cell population expands rapidly to form a regenerative crypt; and (c) normal patterns of epithelial differentiation are reestablished by migration and differentiation of cells produced in these regenerative crypts. One surviving stem cell (clonogenic cell) can repopulate a crypt after injury; moreover, if the injury has completely destroyed some crypts, the surviving crypt stem cells can divide to replete the number of viable crypts (12).

Although it is clear that stem cell proliferation is an important step in epithelial injury repair, this process has been difficult to study because no specific histologic or immunologic characteristics that distinguish intestinal epithelial stem cells from other crypt epithelial cells have been described. Thus, knowledge of the biological characteristics of intestinal stem cells has been largely acquired by inference from experiments using chimeric and transgenic mice $(1,8,13)$, and from studying epithelial regeneration following injury directed at replicating cell populations in the gut (14). A functional assay for quantifying stem cell survival following acute cytotoxic injury to the replicating cell population has been developed based on the capacity of the surviving stem cells to regenerate crypt-like foci of cells (termed microcolonies) $(12,15)$. Although this assay can be used to study epithelial regeneration in response to any cytotoxic insult, the response of the gastrointestinal epithelium to acute radiation injury in the mouse has been the 
most extensively characterized model. The actively proliferating transit cells are the most sensitive to ionizing radiationinduced injury; the slowly proliferating stem cells are less sensitive to radiation. 3 or $4 \mathrm{~d}$ after irradiation, the number of crypt-like foci of surviving epithelial cells is scored on histologic sections of intestine. Each epithelial focus is thought to represent survival of one or more clonogenic stem cell able to give rise to the regenerative crypt.

A number of agents including peptide growth factors and prostaglandins can affect stem cell fate, cell cycle kinetics, and cellular migration pathways both during normal epithelial turnover and during injury repair $(2,3,16,17)$. Exogenous $\mathrm{PGE}_{2}$ produces epithelial hyperplasia in the intestine; the initial kinetic change is a reduction in epithelial cell loss from the villi (18). Inhibition of the synthesis of endogenous prostaglandins by nonsteroidal antiinflammatory drugs (NSAIDs) ${ }^{1}$ was also associated with a decrease in cell proliferation. While NSAID usage is a common cause of gastritis and gastric ulcers and is associated with a significant incidence of intestinal toxicity including ulceration, the molecular mechanisms by which NSAIDs induce gastrointestinal injury or affect mucosal injury repair have not been well defined.

Until recently, cyclooxygenase (the major enzyme for prostaglandin synthesis) was thought to be a single protein; it is now clear, however, that there are two cyclooxygenases: cyclooxygenase-1 (Cox-1), which appears to be a constitutive enzyme, and cyclooxygenase-2 (Cox-2), which is inducible by cytokines, growth factors, and other agents in a number of cell types (19-22). It is likely that Cox-1 and Cox-2 make different contributions to eicosanoid production in different cell types, and also make different contributions to eicosanoid production in the same cell type under different conditions. Inhibitors of cyclooxygenase such as aspirin and other NSAIDS may differ in their effects on Cox-1 and Cox-2 (23-25). Development of inhibitors that are specific for Cox- 1 and Cox-2 may allow selective inhibition of specific biologic effects mediated by eicosanoids without the gastrointestinal side effects associated with currently available nonselective NSAIDs. Despite the interest in this area, the cellular distribution of Cox-1 and Cox-2 in the gastrointestinal tract, and the relative contributions of Cox-1 and Cox-2 to epithelial cell proliferation, wound healing, and gastrointestinal toxicity, are largely unknown.

In this study, we use the microcolony assay following radiation injury to define the role of prostaglandins in the regulation of crypt stem cell survival and proliferation in the mouse intestinal epithelium. Here we report: $(a)$ levels of Cox-1 mRNA are elevated in mouse intestine following radiation-injury; $(b)$ indomethacin (an inhibitor of prostaglandin synthesis through both Cox-1 and Cox-2) decreases $\mathrm{PGE}_{2}$ levels and inhibits stem cell survival when administered $24-48 \mathrm{~h}$ after irradiation; (c) the inhibition of stem cell survival induced by indomethacin is reversed by coadministration of 16,16 -dimethylPGE $;(d)$ selective inhibition of Cox-2 has no effect on stem cell survival after irradiation; and (e) Cox-1 is localized in epithelial cells of the crypt in unirradiated mice, and in regenerative crypt epithelial cells in irradiated mice. We interpret these findings to

1. Abbreviations used in this paper: BrdUrd, 5-bromo-2'-deoxyuridine; Cox-1, cyclooxygenase-1; Cox-2, cyclooxygenase-2; NSAID, nonsteroidal antiinflammatory drug. indicate that $\mathrm{PGE}_{2}$ produced through Cox-1 promotes crypt stem cell survival and/or proliferation following irradiation.

\section{Methods}

Animals. FVB/N female mice (Taconic Farms Inc., Germantown, NY) were maintained on a 12-h light/dark schedule, and fed standard laboratory mouse chow ad libitum. Mice were irradiated at age $6 \mathrm{wk}$ in an irradiator (Gamacel 40 cesium irradiator; Atomic Energy of Canada Limited, Ottawa, Canada) at $0.96 \mathrm{cGy} / \mathrm{min}$. Animals were killed at various times following irradiation, and were rapidly dissected as previously described (7). The proximal jejunum was fixed in Bouin's solution, and divided into eight 5 -mm segments before paraffin embedding and immunohistochemical analysis. The distal jejunum was snap frozen in liquid nitrogen for analysis of $\mathrm{PGE}_{2}$ levels. The ileum was snap frozen in liquid nitrogen, and total cellular RNA was prepared for ribonuclease protection analysis from the frozen tissue using TRIAZOL (GIBCO BRL, Bethesda, MD) according to the manufacturer's directions.

Crypt survival. Crypt survival was measured in animals killed $3.5 \mathrm{~d}$ after irradiation using a modification of the microcolony assay (12, 15). Each mouse received $120 \mathrm{mg} / \mathrm{kg}$ 5-bromo-2'-deoxyuridine (BrdUrd) (Sigma, St. Louis, MO) and $12 \mathrm{mg} / \mathrm{kg}$ 5-fluoro-2'-deoxyuridine (Sigma) $2 \mathrm{~h}$ before death to label the s-phase cells. $5-\mu \mathrm{m}$ paraffin sections were prepared from proximal jejunum oriented so that the sections were cut perpendicular to the long axis of the small intestine. For purposes of the microcolony assay, a regenerative crypt was determined to have survived irradiation based on its histological appearance. The viability of each surviving crypt was confirmed by immunohistochemical detection of BrdUrd incorporation into five or more epithelial cells within each regenerative crypt. A minimum of six complete cross-sections were scored for each mouse.

Immunohistochemical techniques. For detection of incorporated BrdUrd into s-phase cells, deparaffinized sections were incubated with a 1:2000 dilution of affinity-purified goat anti-BrdUrd (26) at $4^{\circ} \mathrm{C}$ overnight following blocking of nonspecific protein binding sites with PBS containing $2 \%$ bovine serum albumin, $0.2 \%$ nonfat dry milk, and $0.3 \%$ Triton X-100. Bound anti-BrdUrd was subsequently visualized with either gold-labeled rabbit anti-goat $\mathrm{IgG}$ with silver enhancement (Amersham Corp., Arlington Heights, IL), or by fluorescence with Cy3-labeled donkey anti-goat IgG or Texas red-labeled donkey anti-goat IgG (Jackson Immunoresearch Labs, Inc., West Grove, PA). For immunohistochemical localization of mouse Cox-1, deparaffinized sections of Bouin's fixed tissue were incubated with a 1:2000 to 1:8000 dilution of rabbit anti-mouse Cox-1 (a gift from $\mathbf{J}$. Masferrer, G.D. Searle, St. Louis, MO) (27). Following quenching of endogenous peroxidase activity with $1 \%$ hydrogen peroxide, sections were washed. Bound rabbit anti-mouse Cox-1 was detected by fluorescein-conjugated tyramide signal amplification (TSA direct; Dupont NEN Life Science Products, Boston, MA) according to the manufacturers directions following incubation with biotin-labeled donkey anti-rabbit IgG (Jackson Immunoresearch Labs., Inc.) and subsequent incubation with streptavidin-horseradish peroxidase.

Cyclooxygenase inhibitors. Indomethacin (Sigma) was dissolved in ethanol and diluted into sterile 5\% sodium bicarbonate immediately before use. The indicated doses of indomethacin were administered by intraperitoneal injection. Two selective Cox-2 inhibitors were used: NS-398 (BIOMOL Res. Labs., Inc., Plymouth Meeting, PA) (28) was dissolved in Methocel and administered intraperitoneally at the indicated times following irradiation; SC57666 (G.D. Searle) (29) was dissolved in Methocel and administered intraperitoneally. The choice of dosages of NS-398 $(1 \mathrm{mg} / \mathrm{kg}$ every $8 \mathrm{~h})$ and SC57666 $(50 \mathrm{mg} / \mathrm{kg}$ every $8 \mathrm{~h})$ was based on the doses that inhibited $\mathrm{PGE}_{2}$ production in vivo in Cox-2 dependent animal models $(28,29)$ without affecting synthesis of $\mathrm{PGE}_{2}$ through Cox-1.

Measurement of Cox-1 and Cox-2 mRNAs levels. Ileal RNA was prepared as described above. Samples $(10 \mu \mathrm{g})$ of total RNA were hybridized with ${ }^{32} \mathrm{P}$-labeled antisense RNA probes corresponding to 



Figure 1. Effect of indomethacin on transit cell replication and crypt survival following $\gamma$-irradiation. FVB/N female mice were treated with either sodium bicarbonate $(A, C$, and $E$ ) or with indomethacin $(3 \mathrm{mg} / \mathrm{kg}$ per d) $(B, D$, and $F)$ and received BrdUrd $2 \mathrm{~h}$ before killing to label s-phase cells. Cells incorporating BrdUrd were detected by goat anti-BrdUrd, and bound antibody was visualized by immunofluorescence using Cy-3-labeled donkey anti-goat $\operatorname{IgG}(A, B, E$, and $F)$. In unirradiated mice who received sodium bicarbonate $(A)$ or indomethacin $(B)$, BrdUrd (yellow fluorescence) was incorporated into s-phase cells within the replicative zone of all intestinal crypts. Indomethacin had no apparent effect on the number of s-phase cells within the crypt epithelium of unirradiated mice. The histological appearance of regenerative crypts appearing $3.5 \mathrm{~d}$ after 12 Gy $\gamma$-irradiation in hematoxylin and eosin-stained sections is shown in $C$ and $D$. The black arrows identify regenerative crypts. Note the substantial decrease in the number of surviving crypts in the irradiated indomethacin-treated mice $(D)$ compared with irradiated controls $(C)$. The height of the villi was decreased to a similar extent in both control and indomethacin-treated mice following irradiation. The viability of regenerative crypts was confirmed by incorporation of BrdUrd into at least five epithelial cells within each regenerative crypt. $E$ and $F$ show immunohistochemical localization of BrdUrd from adjacent sections to those shown in $C$ and $D$, respectively. Surviving crypts are indicated by the white arrows. Note that the number of surviving crypts is reduced markedly in irradiated mice treated with indomethacin-compared to mice treated with vehicle alone. The number of s-phase cells within each regenerative crypt was similar in both indomethacin-treated and control mice following irradiation (compare $E$ and $F$ ). 


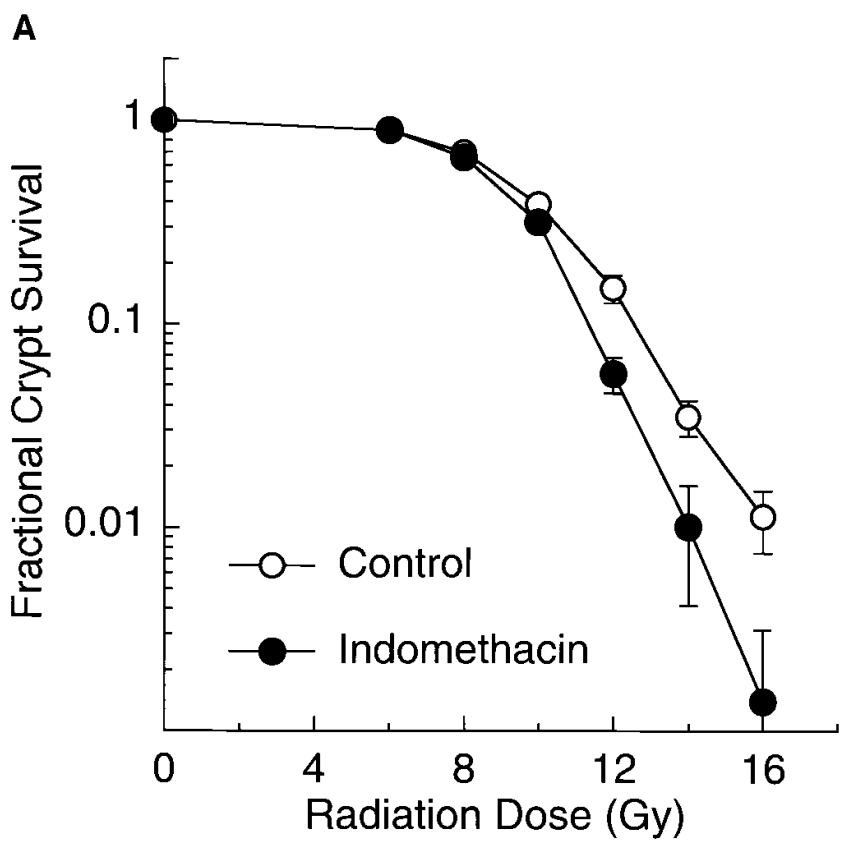

B

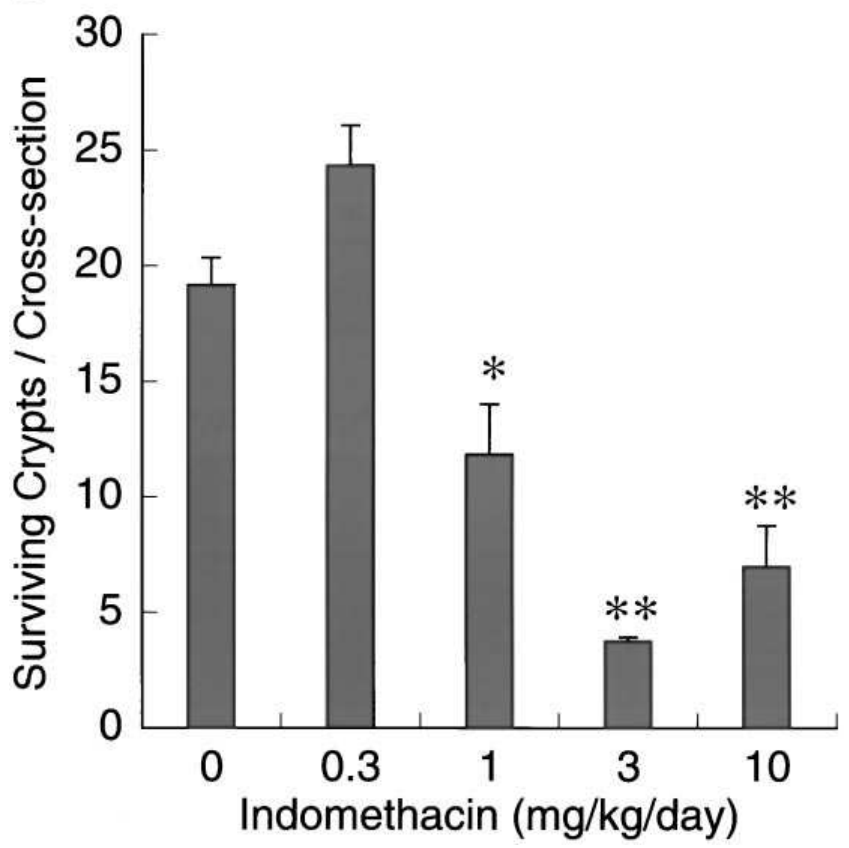

Figure 2. Effect of indomethacin on crypt survival following $\gamma$-irradiation. $(A)$ The effect of radiation dose on fractional crypt survival in control mice $(\bigcirc)$ or mice treated with indomethacin $(\bullet)$ is shown. A surviving crypt is defined as one with greater than five BrdUrdlabeled epithelial cells. Mice were killed, and crypt survival was scored $3.5 \mathrm{~d}$ after a single dose of radiation. Indomethacin-treated mice received $1 \mathrm{mg} / \mathrm{kg}$ every $8 \mathrm{~h}$ beginning $1 \mathrm{~h}$ after irradiation, and continuing until the time of death. Control mice received sodium bicarbonate, the vehicle for indomethacin. Six cross-sections per mouse from three mice were scored for crypt survival for each data point. The data are normalized to the number of BrdUrd-labeled crypts in unirradiated animals. Data for fractional crypt survival are presented as the mean \pm the standard error of mean. $(B)$ The effect of indomethacin dose on the number of surviving crypts per intestinal cross-section is shown. Mice were irradiated with a single dose of 12 Gy. Indomethacin was administered every $8 \mathrm{~h}$ beginning $1 \mathrm{~h}$ after irradiation, and continuing until the time the animals were killed $3.5 \mathrm{~d}$ mouse Cox-1 and Cox-2 (28). Using the RPA II ribonuclease protection kit (Ambion Inc., Austin, TX) according to manufacturer's directions, the Cox- 1 probe hybridized to nucleotides $40-280$ of Cox-1 mRNA, and the Cox-2 probe hybridized to nucleotides 1775-1940 of Cox-2 mRNA. The RNA hybrids were digested with RNase A and $\mathrm{T} 1$ at $37^{\circ} \mathrm{C}$. The protected RNA fragments were separated by electrophoresis in $7.5 \mathrm{M}$ urea $/ 8 \%$ acrylamide sequencing gels. Gels were dried, and autoradiography was performed using Kodak BioMax MR film.

Measurement of $P G E_{2}$ levels. Lipids were extracted by homogenizing flash-frozen tissue in cold ethanol/ $0.1 \mathrm{M}$ sodium phosphate, $\mathrm{pH}$ $4.0(70 \% / 30 \%, \mathrm{vol} / \mathrm{vol})$ followed by shaking incubation at room temperature. An aliquot of the extract was dried down under a stream of nitrogen, and the PGE concentration was determined by a $\mathrm{PGE}_{2^{-}}$ specific ELISA (Cayman Chemical Co., Inc., Ann Arbor, MI) according to the manufacturer's directions.

SDS-PAGE and Western blot analysis of Cox-1 and Cox-2. Intestines from 5-6-wk-old irradiated (12 Gy) and unirradiated mice were homogenized in ice-cold lysis buffer $(1 \mathrm{ml}$; PBS + $10 \mathrm{mM}$ EDTA, $1 \%$ Triton X-100, 0.5\% deoxycholic acid, $1 \mathrm{mM}$ diethyldithiocarbamic acid) containing leupeptin $(10 \mu \mathrm{M})$, pepstatin $\mathrm{A}(1.5 \mu \mathrm{M})$, and aprotinin $(0.2 \mathrm{U} / \mathrm{ml})$. Samples for SDS-PAGE electrophoresis were solubilized in SDS-PAGE sample buffer ( $\mathrm{pH} 6.8)$ containing TRIS (62.5 $\mathrm{mM}$ ), glycerol (10\%), SDS (2\%), bromophenol blue (1\%), and B-mercaptoethanol (5\%). Equal amounts of proteins from the unirradiated and irradiated mouse intestinal lysates and the positive controls (lysates of mouse peritoneal macrophages and of LPS-stimulated RAW cells were gifts of Dr. James Lefkowith, Washington University) were separated by electrophoresis on $7.5 \%$ sodium dodecyl sulfate polyacrylamide gels. After electrophoresis, the separated proteins were transferred to an Immobilon transfer membrane (Millipore Corp., Bedford, MA). Rabbit antibodies against mouse Cox-1 (a gift from J. Masferrer, G.D. Searle) and Cox-2 (Cayman Chemical Co., Inc., Ann Arbor, MI) were used to detect bands corresponding to Cox-1 and Cox-2, respectively. Bound antibody was visualized using a donkey anti-rabbit IgG linked to horseradish peroxidase and ECL (Amersham) with fluorographic detection on Kodak BioMax MR film.

\section{Results}

Indomethacin inhibits crypt survival following $\gamma$-irradiation. The effects of indomethacin (an inhibitor of both Cox-1 and Cox-2) on crypt number and transit cell replication were initially examined in normal adult mice and following 12 Gy $\gamma$-irradiation (Fig. 1). In unirradiated mice, indomethacin treatment for $3 \mathrm{~d}(3 \mathrm{mg} / \mathrm{kg}$ per $\mathrm{d})$ did not affect either the total number of crypts per cross-section or the proportion of crypt cells in s-phase during the 2-h pulse-labeling period (Fig. 1, $A$ and $B$ ). $3.5 \mathrm{~d}$ after radiation, most of the crypt epithelial cells had been killed, and the surviving stem cells had proliferated to form regenerative crypts (Fig. 1, $C$ and $E$ ). Indomethacin treatment for $3 \mathrm{~d}$ after $12 \mathrm{~Gy} \gamma$-irradiation resulted in an apparent decrease in the number of surviving crypts (Fig. 1, $D$ and $F$ ). Radiation also resulted in villus shortening; there was no difference in villus shortening between the mice that received both radiation and indomethacin, and those that received radiation alone (Fig. 1, $C$ and $D$ ). To further define the role of endogenously produced prostaglandins in regulating crypt stem cell survival following radiation injury, the effect of radiation dose

after irradiation. Six cross-sections were scored for each mouse. Data are shown as the mean \pm the standard error of mean for three mice. $* P<0.05$ compared to no indomethacin. $* * P<0.005$ compared to no indomethacin. 
A
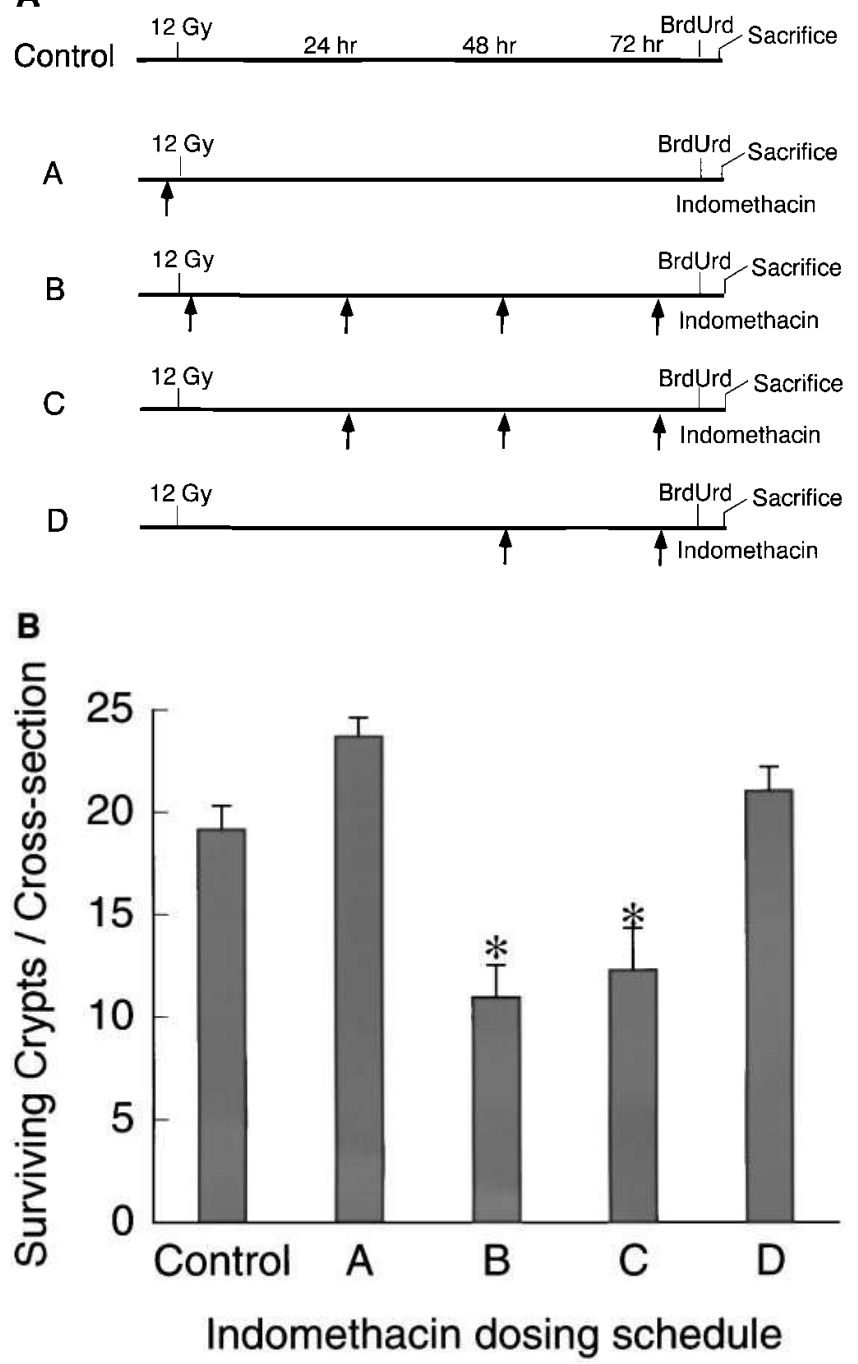

Figure 3. Effects of various indomethacin dosing schedules on crypt survival after irradiation. The upper panel presents five different indomethacin dosing schedules in the period before and after irradiation. The lower panel presents the number of surviving crypts in the intestines of irradiated mice treated with indomethacin in the dosing schedules presented in the upper panel. All mice received a single dose of $12 \mathrm{~Gy} \gamma$-radiation. $82 \mathrm{~h}$ after irradiation, each mouse received an injection of BrdUrd. $2 \mathrm{~h}$ later the animals were killed. Mice in the control group received no indomethacin. Mice in groups A, B, C, and $D$ received intraperitoneal injections of indomethacin at a dose of 1 $\mathrm{mg} / \mathrm{kg}$ at the times indicated by the arrows. In $B$, the number of surviving crypts per jejunal cross-section is shown for each dosing schedule. Three mice were analyzed per treatment group. Data are expressed as the mean number of surviving crypts per crosssection \pm standard error of the mean. $* P<.05$ compared to no indomethacin.

on crypt survival was determined in the presence and absence of indomethacin (Fig. $2 A$ ). A single dose of radiation of $6 \mathrm{~Gy}$ or less had no effect on the number of surviving intestinal crypts 3.5 d postirradiation. Doses between 8 and 16 Gy resulted in a progressive decline in the number of surviving crypts; after a single dose of 16 Gy the number of surviving crypts was just $1 \%$ of that seen with doses below 6 Gy. Treatment with indomethacin $(1 \mathrm{mg} / \mathrm{kg}$ i.p. every $8 \mathrm{~h}$, beginning $1 \mathrm{~h}$ af-
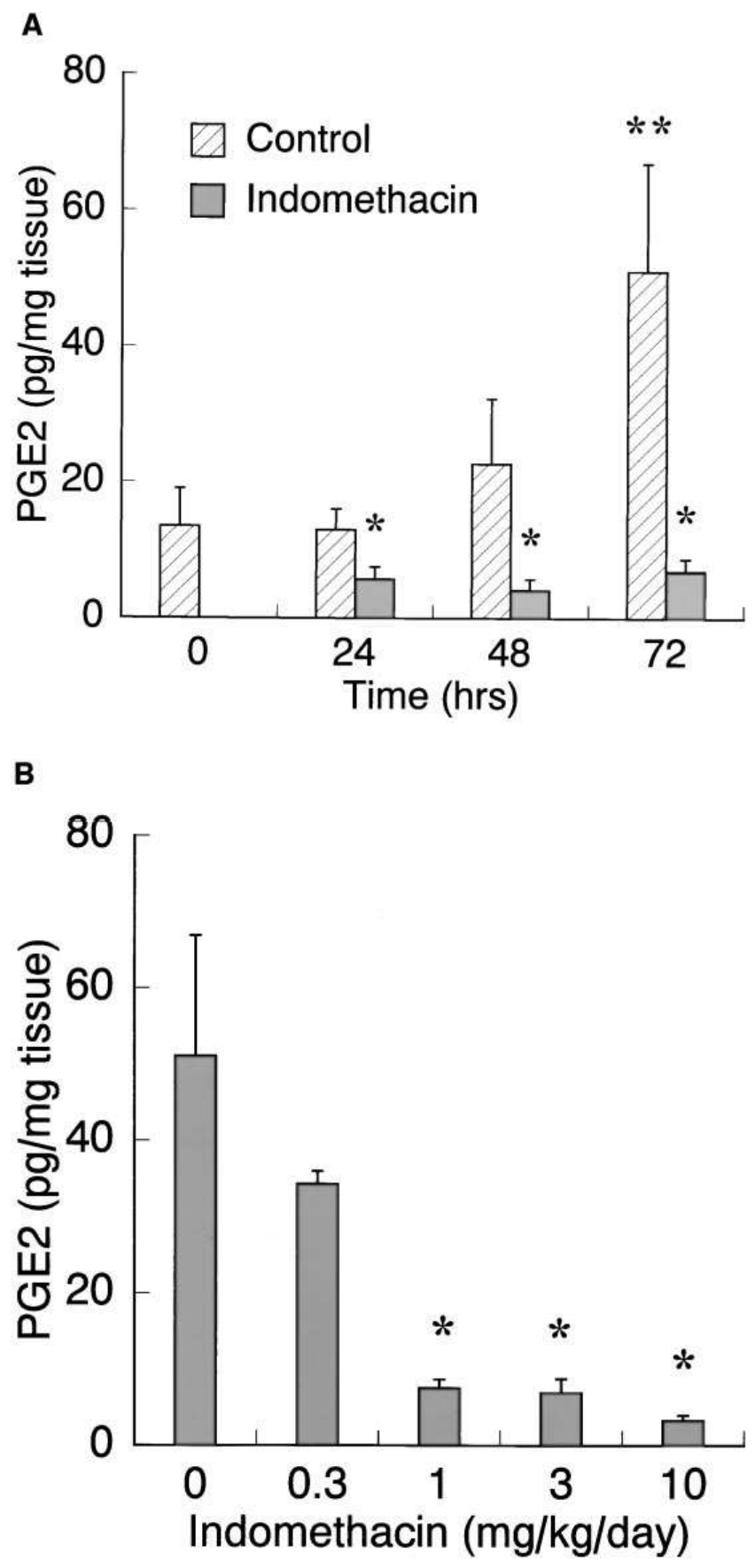

Figure 4. Effects of irradiation and indomethacin on $\mathrm{PGE}_{2}$ levels in the intestine. $(A)$ Intestinal $\mathrm{PGE}_{2}$ levels in mice at various times after a single dose of irradiation ( $12 \mathrm{~Gy}$ ). All mice were irradiated. Indomethacin-treated mice received a dose of $1 \mathrm{mg} / \mathrm{kg}$, every $8 \mathrm{~h}$ beginning $1 \mathrm{~h}$ after irradiation. Three mice were analyzed at each time point. Data are expressed as the mean \pm standard error of the mean. (B) PGE $_{2}$ levels in mouse intestines, $3.5 \mathrm{~d}$ after a single dose of radiation (13 Gy). Indomethacin was administered at the doses indicated on an 8-h schedule beginning $1 \mathrm{~h}$ after irradiation and continuing until the animals were killed $3.5 \mathrm{~d}$ later. ${ }^{*} P<.05$ compared to no indomethacin. $* * P<.05$ compared to preradiation value.

ter irradiation and continuing until the animals were killed $3.5 \mathrm{~d}$ later) reduced the number of surviving crypts at all doses of irradiation. Indomethacin treatment resulted in a $62 \%$ reduction in the number of surviving crypts at $12 \mathrm{~Gy}, 71 \%$ at $14 \mathrm{~Gy}$, 
and $89 \%$ at 16 Gy. Indomethacin treatment after irradiation (12 Gy) resulted in a dose-dependent decrease in crypt survival with a maximal effect at $3 \mathrm{mg} / \mathrm{kg}$ per d (Fig. $2 B$ ). No additional effect was noted at higher doses of indomethacin. The effects of a dose of $3 \mathrm{mg} / \mathrm{kg}$ per d were identical whether the indomethacin was given $1 \mathrm{mg} / \mathrm{kg}$ every $8 \mathrm{~h}$, or $3 \mathrm{mg} / \mathrm{kg}$ every $24 \mathrm{~h}$ (data not shown).

Several indomethacin dosage schedules were used to define the time period of indomethacin sensitivity in regulating crypt survival (Fig. 3). Administration of indomethacin (1 mg/ $\mathrm{kg}$ ) as a single dose $1 \mathrm{~h}$ before irradiation had no effect on crypt survival. Maximal reductions in crypt survival were observed when indomethacin $(1 \mathrm{mg} / \mathrm{kg})$ dosing was begun either at $1 \mathrm{~h}$ after irradiation, or at $24 \mathrm{~h}$ postirradiation, and continued through $72 \mathrm{~h}$ after irradiation. When the initial dose of indomethacin was delayed until $48 \mathrm{~h}$ after irradiation, however, no effect on crypt survival was seen. This experiment suggests that the indomethacin-sensitive event(s) in the determination of crypt survival occur between 24 and $48 \mathrm{~h}$ after irradiation.

$\gamma$-irradiation induces synthesis of intestinal $P G E_{2}$. Intestinal $\mathrm{PGE}_{2}$ levels rose progressively in the period following radiation injury. At $3 \mathrm{~d}$ after irradiation $\mathrm{PGE}_{2}$ levels were 4 times higher than levels present in the intestine before irradiation (Fig. $4 \mathrm{~A}$ ). Treatment with indomethacin $(3 \mathrm{mg} / \mathrm{kg}$ per d) resulted in a $>80 \%$ inhibition of $\mathrm{PGE}_{2}$ production at 48 and $72 \mathrm{~h}$. Intestinal $\mathrm{PGE}_{2}$ levels measured $3.5 \mathrm{~d}$ postirradiation demonstrated a dose response to indomethacin given daily, beginning $1 \mathrm{~h}$ postirradiation (Fig. $4 \mathrm{~B}$ ). The indomethacin dose response for inhibition of $\mathrm{PGE}_{2}$ production paralleled the effect of indomethacin on crypt survival (Figs. $2 B$ and $4 B$ ). Significant reductions were seen in both crypt survival (Fig. $2 B$ ) and $\mathrm{PGE}_{2}$ levels (Fig. $4 \mathrm{~B}$ ) at indomethacin doses higher than 0.3 $\mathrm{mg} / \mathrm{kg}$ per d. Administration of 16,16-dimethylPGE 2 (10 $\mu \mathrm{g}$ i.p. every $8 \mathrm{~h}$ beginning $1 \mathrm{~h}$ after irradiation and continuing for $3.5 \mathrm{~d}$ ) had no effect on crypt survival postirradiation (Fig. 5). Coadministration of 16,16-dimethylPGE $\mathrm{PG}_{2}$ with indomethacin $(3 \mathrm{mg} /$ $\mathrm{kg}$ per $\mathrm{d}$ ), however, partially reversed the decrease in crypt survival seen with indomethacin alone.

Levels of Cox-1 $\mathrm{mRNA}$ and protein are increased following $\gamma$-irradiation. The increase in $\mathrm{PGE}_{2}$ levels observed following irradiation may result from prostaglandin synthesis by either isoform of cyclooxygenase (Cox-1 or Cox-2). To determine which cyclooxygenase isoform was involved, Cox-1 and Cox-2 mRNA and protein levels were examined before and after ir- radiation. The expression of Cox- 1 and Cox- 2 mRNA in the intestine was measured by ribonuclease protection assays. In the unirradiated intestine there was approximately 35-fold more Cox-1 than Cox-2 mRNA (Fig. 6 B). After irradiation with $13 \mathrm{~Gy}$, Cox-1 mRNA increased progressively, reaching maximal levels fivefold above the levels present in unirradiated mice at $96 \mathrm{~h}$ after irradiation (Fig. 6, $A$ and $B$ ). Cox-2 mRNA levels also increased slightly from $48-96 \mathrm{~h}$ after irradiation. The absolute levels of Cox- 2 mRNA, however, remained much lower than the levels of Cox-1 mRNA present in unirradiated mice, or present at any time following irradiation. Lower doses of radiation (6-8 Gy) resulted in reduced Cox-1 mRNA at $3.5 \mathrm{~d}$ after irradiation, whereas higher doses of radiation (10-14 Gy) resulted in increased Cox-1 mRNA expression (Fig. 6, $C$ and $D$ ). Cox-2 mRNA levels were unaffected by radiation dose in this experiment. Thus, the radiation doses that caused the greatest reduction in the number of surviving crypts were associated with the greatest increase in Cox-1 mRNA expression. The increase in Cox- 1 mRNA induced by radiation injury (12 Gy) was associated with a similar increase in Cox-1 protein as assessed by Western blotting (Fig. 7). Cox-2 protein was not identified in either unirradiated or irradiated intestine by Western blotting. The finding that Cox-1, but not Cox-2, protein was detected by Western blotting was not surprising in view of the much larger amounts of Cox-1 mRNA on ribonuclease protection assays (Fig. 6).

Crypt survival is not affected by selective inhibition of Cox-2. To determine which cyclooxygenase is the source of the $\mathrm{PGE}_{2}$ which mediates intestinal stem cell survival after irradiation, crypt survival was examined following treatment of irradiated animals with indomethacin, an inhibitor of both Cox- 1 and Cox-2, or with either of two structurally different selective Cox-2 inhibitors. Treatment of the irradiated mice with either of the two different selective Cox-2 inhibitors, SC57666 or NS398 , had no effect on intestinal $\mathrm{PGE}_{2}$ levels present at $48 \mathrm{~h}$ after irradiation (SC57666, 135\% of control; NS-398, 111\% of control), whereas indomethacin treatment resulted in a marked decrease in intestinal PGE2 (3\% of control $\left.\mathrm{PGE}_{2}\right)$. In contrast to the reduction in crypt survival seen with indomethacin, there was no effect on crypt cell survival in irradiated mice treated with either of the selective Cox-2 inhibitors, NS-398 or SC57666 $(28,29)$ (Fig. 8).

Cellular localization of Cox-1 following irradiation. Immunohistochemical analysis of Cox-1 in the small intestine of normal

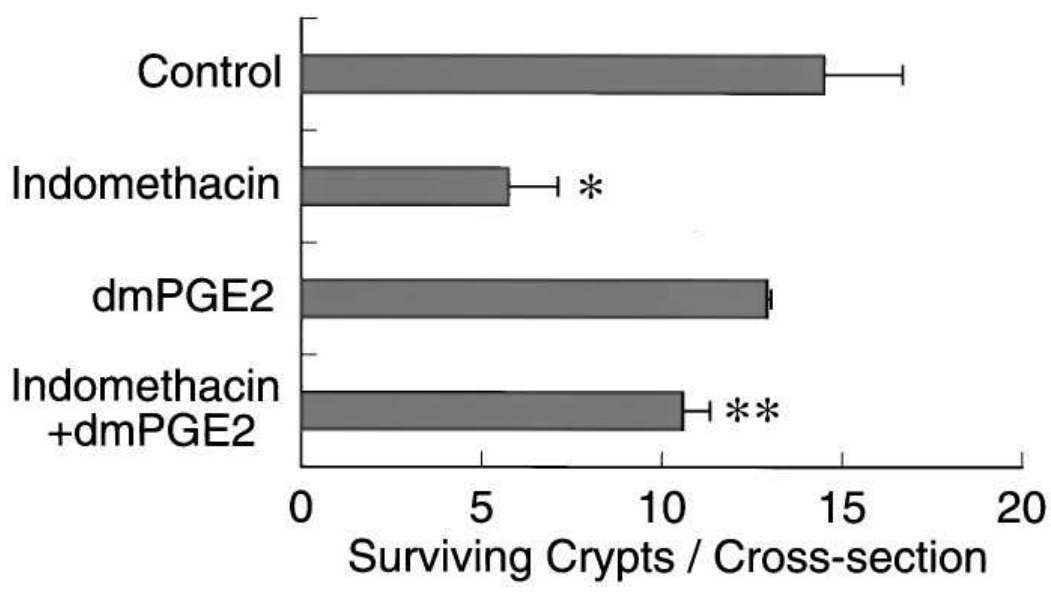

Figure 5. Effect of 16,16-dimethylPGE $\mathrm{P}_{2}$ on crypt survival after irradiation. All mice received a single dose of irradiation (13 Gy). Indomethacin-treated mice received a dose of $1 \mathrm{mg} / \mathrm{kg}$ every $8 \mathrm{~h}$ beginning $1 \mathrm{~h}$ after irradiation and continuing until the animals were killed 3.5 d later. Animals treated with 16,16dimethylPGE ${ }_{2}\left(\mathrm{dmPGE}_{2}\right)$ received $10 \mu \mathrm{g}$ per mouse every $8 \mathrm{~h}$ on the same schedule. Three mice were analyzed per treatment group. Data are expressed as the mean number of surviving crypts per crosssection \pm standard error of the mean. ${ }^{*} P<.05$ compared to controls. $* * P<.05$ compared to indomethacin alone. 
A Time (hrs)

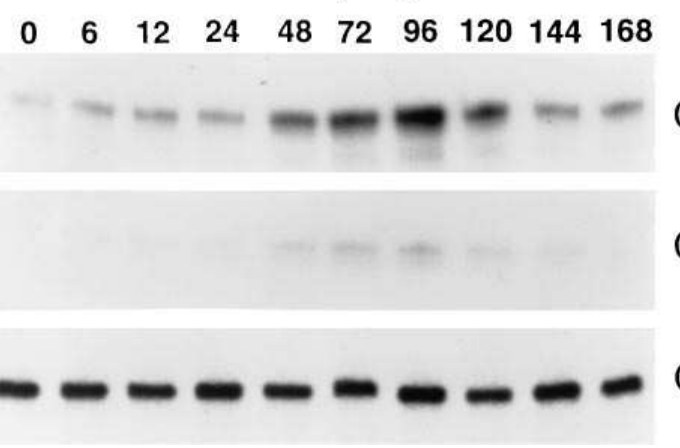

B

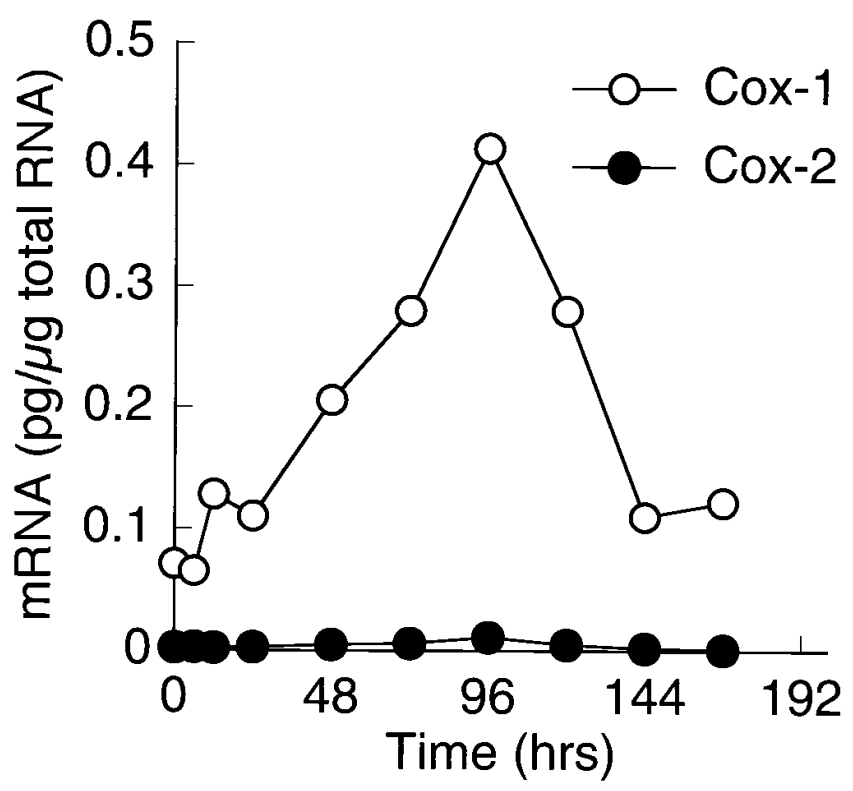

C

Radiation Dose (Gy)

$\begin{array}{llllll}0 & 6 & 8 & 10 & 12 & 14\end{array}$

Cox-1

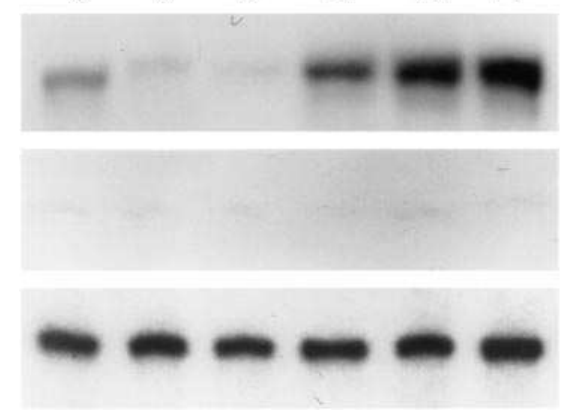

Cox-1

Cox-2

GAPDH

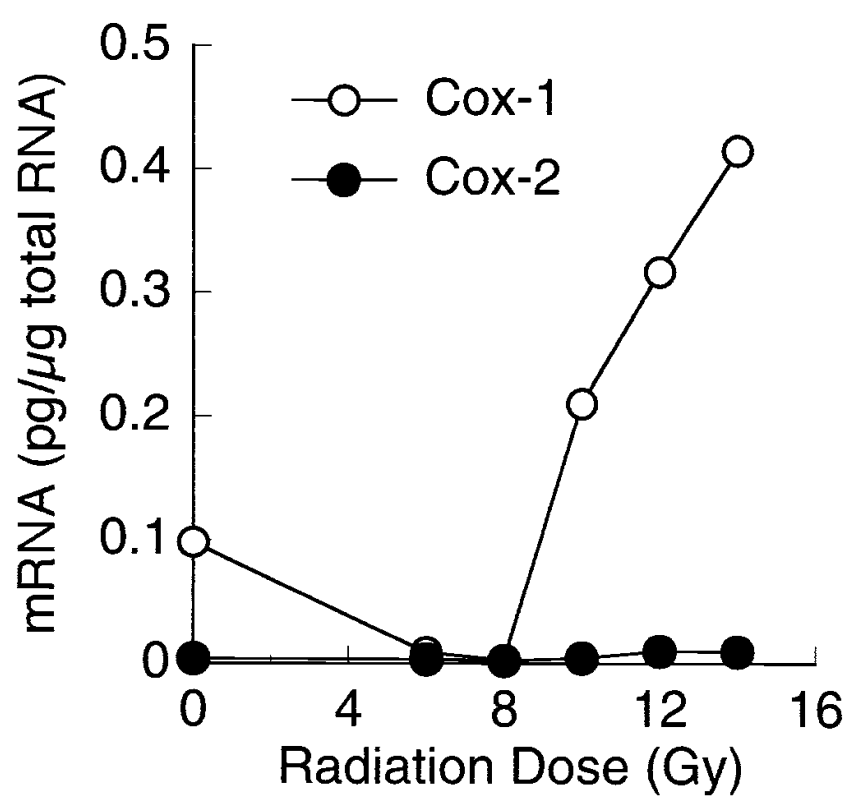

Figure 6. Cox-1 and Cox-2 mRNA levels following irradiation in the mouse small intestine. (A) Small intestinal Cox-1, Cox-2, and GAPDH mRNA levels were determined by ribonuclease protection assays at various times after a single dose of irradiation (13 Gy). Protected bands were seperated by polyacrylamide gel electrophoresis under denaturing conditions, and the gels were analyzed by autoradiaography. Autoradiographs for Cox-1 were exposed for $2 \mathrm{~d}$, Cox-2 autoradiographs for $5 \mathrm{~d}$, and GAPDH autoradiographs for $14 \mathrm{~h}$. (B) Quantitation of the ribonuclease protection assays for Cox-1 and Cox-2 shown in $A$. The intensity of the major protected band for Cox-1 and Cox-2 mRNAs was determined by scanning densitometry on autoradiographs of the ribonuclease protection assays at each time point, and compared to the intensity of bands produced with known amounts of in vitro-transcribed sense-strand control mRNAs for murine Cox-1 and Cox-2. Data were normalized for the abundance of GAPDH mRNA present in each sample. Data are the average Cox-1 and Cox-2 mRNA levels determined from analysis of two mice for each time point. $(C)$ The radiation dose-response for expression of Cox-1, Cox-2, and GAPDH mRNA was determined by ribonuclease protection assays in mouse small intestine $72 \mathrm{~h}$ after irradiation. Protected bands were seperated by denaturing polyacrylamide gel electrophoresis, and autoradiaography of gels was performed as described for $A$. $(D)$ Quantitation of the ribonuclease protection assays for Cox-1 and Cox-2 presented in $C$ is shown. Levels of Cox-1 and Cox-2 mRNA were determined at each radiation dose as described for $B$. Data are expressed as the average Cox-1 and Cox-2 mRNA levels determined from analysis of two mice for each radiation dose.

unirradiated mice demonstrated selective localization of immunoreactive Cox-1 within the cytoplasm of crypt epithelial cells (Fig. 9, $A-D$ ). Cox-1 immunoreactivity was lost within the first $2-3$ cell positions above the crypt-villus junction. There were also a few scattered mononuclear cells in the lamina propria that expressed detectable levels of Cox-1. The vast majority of cells containing immunoreactive Cox-1 in the intestine, however, were in the epithelial cell population. Dual localization of Cox-1 and BrdUrd revealed Cox-1 immunoreactivity in all actively proliferating (BrdUrd positive) epithelial cells within the crypt. $3 \mathrm{~d}$ after 14 Gy $\gamma$-irradiation, the number of cells per cross-section containing immunoreactive Cox-1 was markedly reduced; only epithelial cells within the regenerating crypts were positive (Fig. 10). All of the s-phase cells within each regenerative crypt also contained immunoreactive Cox-1 (Fig. 10, $B$ and $C$ ). Epithelial staining was undetectable in adjacent control sections in which normal rabbit preimmune sera was substituted for the Cox-1 primary antibody (Fig. 10D).

\section{Discussion}

In this study we have demonstrated that levels of Cox-1 are elevated in the mouse intestine following irradiation and that indomethacin, an inhibitor of prostaglandin synthesis through 


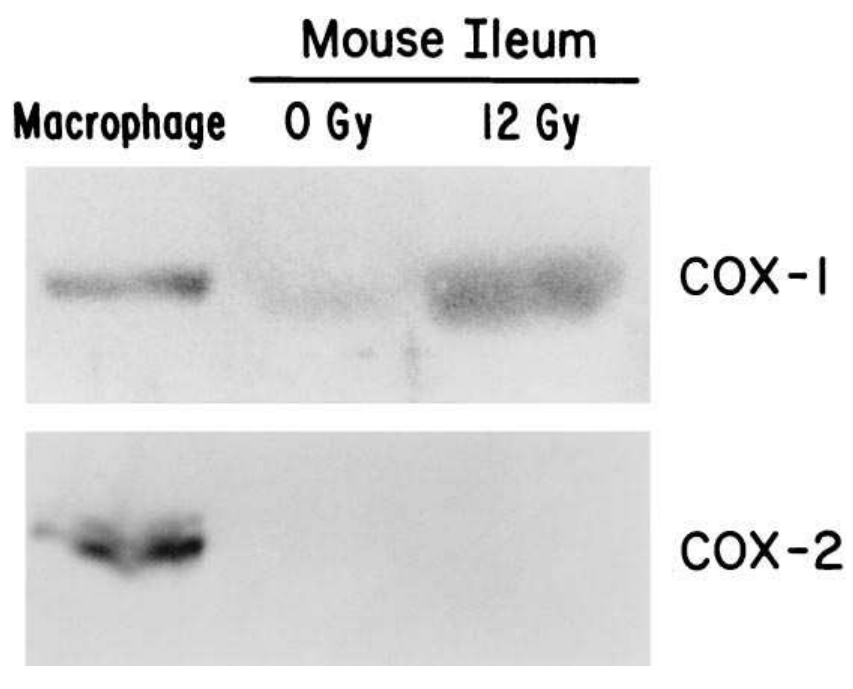

Figure 7. Detection of Cox-1 and Cox-2 in irradiated and nonirradiated mouse ileum by Western blotting. Intestinal lysates were made of nonirradiated mice, and mice $3.5 \mathrm{~d}$ after irradiation with a single dose of $12 \mathrm{~Gy}$. Equal amounts of protein from the nonirradiated and irradiated mouse intestinal lysates and positive controls for Cox-1 (lysates of mouse peritoneal macrophages) and for Cox-2 (lysate of LPS-stimulated RAW cells) were separated by electrophoresis on $7.5 \%$ sodium dodecyl sulfate polyacrylamide gels. Bands corresponding to Cox- 1 and Cox- 2 were detected by ECL using rabbit antibodies against mouse Cox-1 and Cox-2.

Cox-1 and Cox-2, both decreases $\mathrm{PGE}_{2}$ levels, and inhibits the ability of intestinal stem cells to regenerate crypts when administered $24-48 \mathrm{~h}$ after irradiation. In contrast, selective inhibition of Cox-2 had no effect on $\mathrm{PGE}_{2}$ levels or crypt regeneration.

In normal control mice, immunoreactive Cox-1 was predominantly found in epithelial cells of the crypt. In irradiated mice, Cox-1 immunoreactivity was localized almost exclusively to the cytoplasm of regenerating crypt epithelial cells with staining that was much more intense than the crypt epithelial staining observed in the unirradiated control mice. These immunohistochemical findings combined with the marked increase in Cox- 1 protein and mRNA observed in the irradiated intestine, suggest that radiation injury is associated with an induction of Cox-1 gene expression in regenerating stem cells and/or their immediate progeny. The increase in Cox-1 production on a per cell basis is likely much greater than the fivefold increase in mRNA (Fig. 6) or protein (Fig. 7) because the number of surviving crypts (Figs. 2 and 10) and hence the number of Cox-1 expressing cells is markedly decreased at the same time that tissue Cox-1 mRNA and protein levels are increased.

The restricted localization of Cox-1 to epithelial cells of the crypt suggests that intestinal epithelial cells extinguish expression of Cox-1 as they migrate onto the villus. Furthermore, it is likely that there is rapid turnover of Cox-1 as intestinal epithelial cells differentiate since Cox-1 immunoreactivity is lost within the first two to three cell positions above the crypt-villus junction. We found that Cox- 1 is expressed in all replicating crypt epithelial cells, and that Cox-1 immunoreactivity extends several cell positions higher than the upper limits of the proliferative zone as assessed by BrdUrd incorporation. A recent

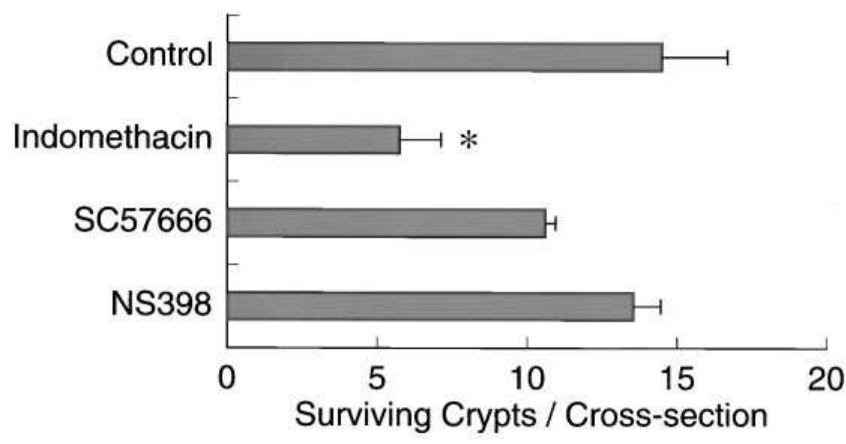

Figure 8. Effects of indomethacin and specific Cox-2 inhibitors on crypt survival after irradiation. All animals received a single dose of irradiation (13 Gy). Indomethacin was given at a dose of $1 \mathrm{mg} / \mathrm{kg}$ every $8 \mathrm{~h}$ beginning $1 \mathrm{~h}$ after irradiation and continuing until the animals were killed $3.5 \mathrm{~d}$ later. NS398 was given at a dose of $1 \mathrm{mg} / \mathrm{kg}$ every $8 \mathrm{~h}$ on the same schedule, and SC57666 was given at a dose of $50 \mathrm{mg} / \mathrm{kg}$ every $8 \mathrm{~h}$ on the same schedule. Three mice were analyzed for each treatment group. Data are presented as the mean number of surviving crypts per cross-section \pm standard error of the mean. $* P<.005$ compared to controls.

study has also demonstrated that Cox- 1 expression in the rat stomach is predominantely found in mucous neck epithelial cells within the proliferative zone of gastric glands, a region that shares many functional similarities to the crypt epithelium in the small intestine (30). Whether the loss of Cox-1 expression as the epithelial cells move onto the lower villus is related to the loss of proliferative capacity, or to the differentiation of these cells into mature villus-associated epithelial cells, is unclear. However, Cox-1 expression is not an absolute requirement for proliferation, as is demonstrated by the histologically normal small intestinal epithelium in Cox-1 knockout mice (31).

The induction of Cox-1 in the regenerating crypts by irradiation could either be due to a direct effect of radiation-injury on the stem cells, or to an indirect effect mediated by the radiation-induced production of a cytokine or other mediator by another cell type. Ionizing radiation can directly induce the expression of a number of regulatory genes in mammalian cells, including early response genes such as c-jun, Egr-1, c-fos, and $N F k B$ (32). A number of secreted proteins including growth factors, however, may also be produced by endothelial cells and other cell types in response to radiation injury (33), suggesting the possibility that Cox-1 expression might also be regulated through extracellular signaling mechanisms. Although Cox-1 has been described as a constitutive enzyme (whereas synthesis of Cox-2 has been shown to be inducible), it is now clear that Cox-1 can also be induced by cytokines under appropriate circumstances. For example c-kit ligand, either alone or in combination with IL-3, IL-9, or IL-10, was able to induce expression of Cox-1 in mouse mast cells (34). Similarly, stem cell factor, especially when combined with dexamethasone, can induce Cox-1 expression in these cells (35). A recent study also demonstrated induction of Cox-1 synthesis in cells following treatment with basic FGF, although with a prolonged time course compared to induction of Cox-2 expression (36). Whether the induction of Cox-1 by radiation is a direct effect of radiation injury on epithelial cell gene expression, or is mediated through the actions of radiation-induced cytokines and/ or growth factors, has not yet been established. 

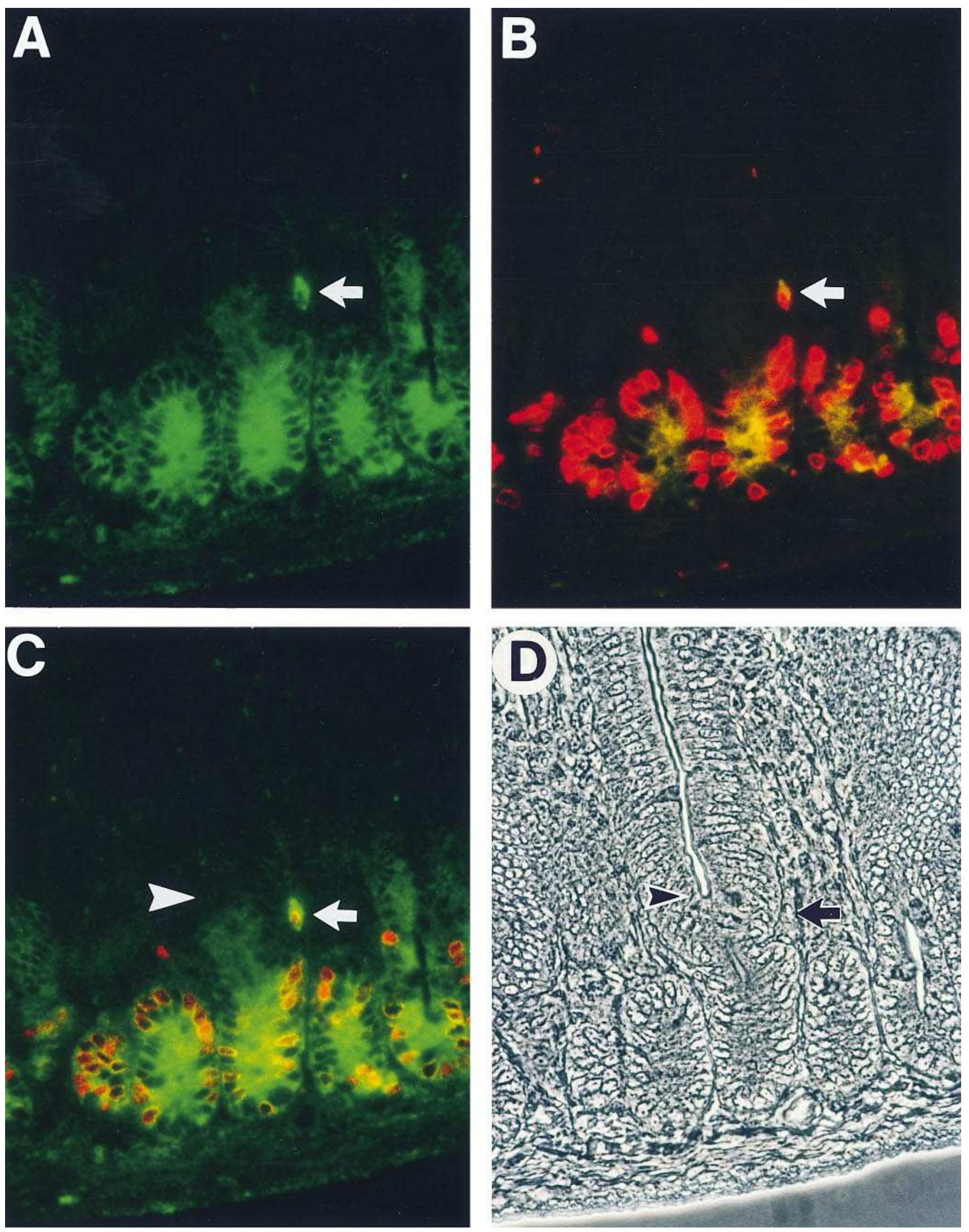

Figure 9. Immunohistochemical localization of Cox-1 in the small intestine of normal adult mice. The cellular localization of Cox-1 was analyzed in normal 6-wk-old FVB/n female mice. All mice received BrdUrd $2 \mathrm{~h}$ before killing to label s-phase cells. Jejunal tissue was fixed in Bouin's solution, and $6 \mu \mathrm{m}$ paraffin sections were prepared for immunohistochemistry. Immunoreactive Cox-1 was detected by incubation with rabbit anti-mouse Cox-1 at a 1:2000 dilution $(A$ and $C)$, and bound antibody was visualized using the fluorescein-conjugated tyramide signal amplifica- 
It is likely that the increase in Cox-1 levels following irradiation is responsible for the significant increase in $\mathrm{PGE}_{2}$ levels. After radiation, the levels of Cox- $1 \mathrm{mRNA}$ and $\mathrm{PGE}_{2}$ increase proportionately and with parallel time courses. In addition, the increase in Cox-1 protein on Western blot is proportionate to the increases in Cox- 1 mRNA and $\mathrm{PGE}_{2}$ levels. These data argue that the increase in $\mathrm{PGE}_{2}$ levels seen after radiation in the intestine is due, at least in part, to increased synthesis of Cox-1.

Treatment with indomethacin after irradiation caused a reduction in the number of surviving crypts, as measured by the microcolony assay. Crypt survival is the result of the successful completion of a series of steps in the time after irradiation (11, 12). First, intestinal stem cells in the base of the crypt must survive radiation injury. Then these surviving stem cells must replicate and give rise to the more actively proliferating transit cell population. Finally, the transit cells must actively proliferate to expand their numbers. Which of these steps are affected by indomethacin is not clear.

The critical period for the effect of indomethacin on crypt survival was $24-48 \mathrm{~h}$ after irradiation. Both Cox-1 mRNA and $\mathrm{PGE}_{2}$ levels had begun to rise by $24-48 \mathrm{~h}$ after irradiation, however, they both continued to rise through and beyond this period. Thus, the period of maximum indomethacin sensitivity preceded the period of maximal Cox- 1 mRNA expression and maximum $\mathrm{PGE}_{2}$ production. The likely explanation is that an important prostaglandin-sensitive step in the regulation of crypt survival occurs $24-48 \mathrm{~h}$ after radiation. At $24 \mathrm{~h}$ after irradiation, intestinal $\mathrm{PGE}_{2}$ levels were $13 \mathrm{pg} / \mathrm{mg}$ tissue, and rose to $22 \mathrm{pg} / \mathrm{mg}$ tissue by $48 \mathrm{~h}$. In the indomethacin-treated animals, $\mathrm{PGE}_{2}$ levels were $<6 \mathrm{pg} / \mathrm{mg}$ tissue at both time points. When these $\mathrm{PGE}_{2}$ levels are correlated with crypt survival (determined by the microcolony assay), the results suggest that during this critical period, levels of $\mathrm{PGE}_{2}>6 \mathrm{pg} / \mathrm{mg}$ tissue are required for optimal crypt survival.

All of the effects of indomethacin are not necessarily related to the inhibition of eicosanoid synthesis; at high doses indomethacin also has other pharmacological effects. There are considerable data, however, supporting the suggestion that the effects of indomethacin on crypt survival after radiation injury are related to inhibition of prostaglandin synthesis. The dose response curve for the effects of indomethacin on crypt survival was consistent with the dose response for indomethacin inhibition of $\mathrm{PGE}_{2}$ synthesis. Moreover, the reduction in crypt survival induced by indomethacin was reversed by the addition of exogenous dimethylPGE $\mathrm{F}_{2}$. This finding suggests not only that the effects of indomethacin on crypt survival were mediated by eicosanoid production, but also that the specific eicosanoid involved is $\mathrm{PGE}_{2}$. DimethylPGE $\mathrm{PG}_{2}$ binds to the same receptors as $\mathrm{PGE}_{2}$, but not to receptors which bind other eicosanoids such as thromboxane A2 or prostacyclin (37).

Crypt survival after irradiation is inhibited by indomethacin, an inhibitor of both Cox-1 and Cox-2, but not by either of two structurally dissimilar selective Cox-2 inhibitors. Moreover, the selective Cox-2 inhibitors did not reduce $\mathrm{PGE}_{2}$ levels. These data suggest that the prostaglandins that are important in the regulation of crypt survival following epithelial injury are produced through Cox-1. Cox-1 is present in far greater abundance than Cox-2 in the intestine after radiation injury. In other injury models which are marked by inflammation, Cox-2 would be expected to be present in greater abundance. Thus, it is possible that prostaglandins produced by Cox-2 may also play a role in stem cell survival and proliferation following injury induced by other agents. Nonetheless, an important role for prostaglandins produced through Cox-1 in the regulation of stem cell proliferation and epithelial wound repair would be consistent with the suggestion that the intestinal side effects of combined Cox-1 and Cox-2 inhibitors such as aspirin and indomethacin, derive from the inhibition of Cox-1 rather than Cox-2. The ulcerogenic effects of NSAIDs may be related in part to defects in epithelial wound healing that are seen when stem cell proliferation and/or survival is impaired.

The role of prostaglandins in the regulation of intestinal injury by radiation has been investigated previously (2). These studies demonstrated that crypt survival following irradiation was enhanced when high doses of exogenous prostaglandins were administered before irradiation. The effects of inhibiting prostaglandin synthesis either before or after irradiation were not investigated. We also observed that administration of superphysiological amounts of exogenous prostaglandins to animals before irradiation increased the number of surviving crypts, confirming the results of these prior studies (data not shown). When we administrated a dose of indomethacin $1 \mathrm{~h}$ before irradiation, however, which was sufficient to decrease intestinal prostaglandin levels) crypt survival was not affected. These studies taken together with the data presented here demonstrate that increasing the level of prostaglandins present above the levels normally found in the uninjured small intestine immediately before irradiation enhances intestinal crypt survival. In contrast, increasing prostaglandin levels above those present in the small intestine after injury has no affect on crypt survival, while reducing prostaglandin levels $24-48 \mathrm{~h}$ after irradiation inhibited subsequent crypt survival. Thus, there are at least two distinct prostaglandin-sensitive time periods affecting the number of surviving crypts following radiation injury.

Mice that are unable to express either Cox-1 or Cox- 2 have recently been reported, and have suprisingly little gastrointestinal pathology $(31,38)$. Mice homozygous for a disrupted Cox-1 gene had no gross or microscopic pathological changes in the gastrointestinal tract, and showed less gastric ulceration than wild-type mice after gavage with indomethacin (31). Similarly, mice deficient in Cox-2 also showed no spontaneous gastric ulcerations or accompanying histopathological abnormalities of the intestinal epithelium (38). These studies demonstrate that neither Cox-1 or Cox-2 are essential for the

tion technique (green fluorescence). S-phase cells incorporating BrdUrd were detected by goat anti-BrdUrd, and bound antibody was visualized by immunofluorescence using Texas red-labeled donkey anti-goat $\operatorname{IgG}(B$ and $C)$ (red fluorescence). $D$ is a phase contrast photomicrograph of the section shown in panels $A-C$. In normal mice, Cox-1 immunoreactivity is abundant in the cytoplasm of crypt epithelial cells (compare $A$ and $D$ ) as well as a few scattered mononuclear cells in the lamina propria (solid arrow). $B$ shows the distribution of s-phase cells in this same section. $C$ is a double exposure of $A$ and $B$ to illustrate the relationship of Cox-1 expression to replicating cells within the crypt epithelium in normal mice. Note that all of the s-phase cells contain abundant immunoreactive Cox-1, and that Cox- 1 immunoreactivity is lost within 2-3 cell positions above the crypt-villus junction (arrowheads; compare $A$ and $C$ with $D$ ). 

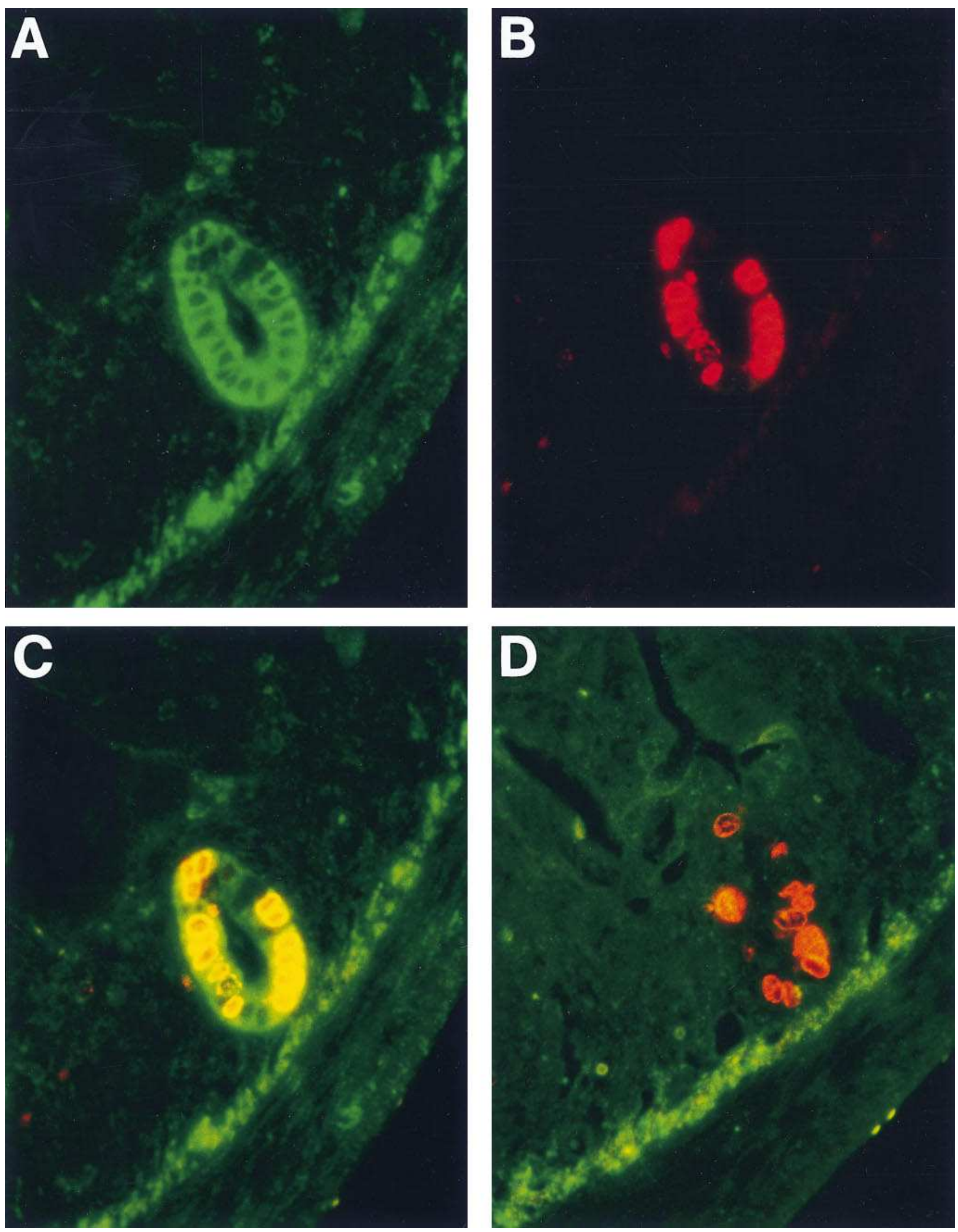

Figure 10. Immunohistochemical localization of Cox-1 in the small intestine of mice following $\gamma$-irradiation. The cellular localization of Cox-1 was analyzed in FVB/n mice killed $3 \mathrm{~d}$ after $14 \mathrm{~Gy} \gamma$-irradiation. All mice received BrdUrd $2 \mathrm{~h}$ before killing to label s-phase cells. Jejunal tissue was fixed in Bouin's solution, and 6- $\mu \mathrm{m}$ paraffin sections were prepared for immunohistochemistry. Immunoreactive Cox-1 was detected by incubation with rabbit anti-mouse Cox-1 at a 1:8000 dilution $(A$ and $C)$, and bound antibody was visualized using the fluorescein-conjugated tyramide signal amplification technique (green fluorescence). S-phase cells incorporating BrdUrd were detected by goat anti-BrdUrd, and bound an- 
maintenance of gastrointestinal integrity in basal unstressed conditions. The results presented here, which demonstrate a role for $\mathrm{PGE}_{2}$ produced through Cox-1 in mediating crypt survival after irradiation, are not inconsistent with the relative paucity of gastrointestinal pathology in the cyclooxygenase knockout studies, but rather demonstrate that prostaglandins produced through these cyclooxygenases may not be important in unstressed conditions, and yet play an important role in the response to epithelial injury.

\section{Acknowledgments}

These studies were supported by the United States Public Health Service Grants R01 DK-33165 (W.F. Stenson), R01 DK-50924 (S.M. Cohn), and R01 HD-31914 (S.M. Cohn), a grant from the Crohn's and Colitis Foundation of America, and a generous gift from the Ladies Auxiliary of the Veterans of Foreign War, Missouri Chapter. S.M. Cohn is a recipient of Glaxo Institute of Digestive Health Basic Research Award, and is an American Gastroenterological Association Procter and Gamble Research Scholar.

\section{References}

1. Gordon, J.I., and M.L. Hermiston. 1994. Differentiation and self-renewal in the mouse gastrointestinal epithelium. Curr. Opin. Cell Biol. 6:795-803.

2. Hanson, W.R., and C. Thomas. 1983. 16, 16-dimethyl prostaglandin $E_{2}$ increases survival of murine intestinal stem cells when given before photon radiation. Radiat. Res. 96:393-398.

3. Goodlad, R.A., C.Y. Lee, S. Levin, and N.A. Wright. 1991. Effects of the prostaglandin analogue misoprostol on cell proliferation in the canine small intestine. Exp. Physiol. 76:561-566.

4. Giovannucci, E., K.M., Egan, D.J. Hunter, M.J. Stampfer, G.A. Colditz, W.C. Willett, and F.E. Speizer. 1995. Aspirin and the risk of colorectal cancer in women. N. Engl. J. Med. 333:609-614.

5. Giovannucci, E., E.B. Rimm, M.J. Stampfer, G.A. Colditz, A. Ascherio, and W.C. Willett. 1994. Aspirin use and the risk for colorectal cancer and adenoma in male health professionals. Ann. Intern. Med. 121:241-246.

6. Cheng, H., and C.P. Leblond. 1974. Origin, differentiation and renewal of the four main epithelial cell types in the mouse small intestine. V. Unitarian theory of the origin of the four epithelial cell types. Am. J. Anat. 141:537-561.

7. Cohn, S.M., T.C. Simon, K.A. Roth, E.H. Birkenmeier, and J.I. Gordon. 1992. Use of transgenic mice to map cis-acting elements in the intestinal fatty acid binding protein gene (Fabpi) that control its cell lineage-specific and regional patterns of expression along the duodenal-colonic and crypt-villus axes of the gut epithelium. J. Cell Biol. 119:27-44.

8. Schmidt, G.H., M.M. Wilkinson, and B.A.J. Ponder. 1985. Cell migration pathway in the intestinal epithelium: an in situ marker system using mouse aggregation chimeras. Cell. 40:425-429.

9. Winton, D.J., and B.A. Ponder. 1990. Stem-cell organization in mouse small intestine. Proc. R. Soc. Lond. B. Biol. Sci. 241:13-18.

10. Potten, C.S., and M. Loeffler. 1987. A comprehensive model of the crypts of the small intestine of the mouse provides insight into the mechanisms of cell migration and the proliferation hierarchy. J. Theor. Biol. 127:381-391.

11. Potten, C.S., and M. Loeffler. 1990. Stem cells: attributes, cycles, spirals, pitfalls and uncertainties. Lessons for and from the crypt. Development. (Camb.). 110:1001-1020.

12. Potten, C.S. 1990. A comprehensive study of the radiobiological response of the murine (BDF1) small intestine. Int. J. Radiat. Biol. 58:925-973.

13. Hauft, S.M., S.H. Kim, G.H. Schmidt, S. Pease, S. Rees, S. Harris, K.A. Roth, J.R. Hansbrough, S.M. Cohn, D.J. Ahnen, N.A. Wright, R.A. Goodlad, and J.I. Gordon. 1992. Expression of SV-40 T antigen in the small intestinal epi- thelium of transgenic mice results in proliferative changes in the crypt and reentry of villus-associated enterocytes into the cell cycle but has no apparent effect on cellular differentiation programs and does not cause neoplastic transformation. J. Cell Biol. 117:825-839.

14. Roberts, S.A., J.H. Hendry, and C.S. Potten. 1995. Deduction of the clonogen content of intestinal crypts: A direct comparison of two-dose and multiple-dose methodologies. Radiat. Res. 141:303-308.

15. Withers, H.R., and M.M. Elkind. 1970. Microcolony survival assay for cells of mouse intestinal mucosa exposed to radiation. Int. J. Radiat. Biol. 117: 261-267.

16. Dignass, A.U., S. Tsunekawa, and D.K. Podolsky. 1994. Fibroblast growth factors modulate intestinal epithelial cell growth and migration. Gastroenterology. 106:1254-1262.

17. Uribe, A., M. Alam, and T. Midtvedt. 1992. $\mathrm{E}_{2}$ prostaglandins modulate cell proliferation in the small intestinal epithelium of the rat. Digestion. 52:157164

18. Uribe, A., C. Johansson, and C. Rubio. 1987. Cell proliferation of the rat gastrointestinal mucosa after treatment with $\mathrm{E}_{2}$ prostaglandins and indomethacin. Digestion. 36:238-245.

19. Kujubu, D.A., B.S. Fletcher, B.C. Varnum, R.W. Lim, and H.R. Herschman. 1991. TIS10, a phorbol ester tumor promoter-inducible mRNA from swiss $3 \mathrm{~T} 3$ cells, encodes a novel prostaglandin synthase/cyclooxygenase homologue. J. Biol. Chem. 266:12866-12872.

20. Maier, J.A.M., T. Hla, and T. Maciag. 1990. Cyclooxygenase is an immediate-early gene induced by interleukin-1 in human endothelial cells. J. Biol. Chem. 265:10805-10808.

21. Masferrer, J.L., K. Seibert, B. Zweifel, and P. Needleman. 1992. Endogenous glucocoricoids regulate an inducible cyclooxygenase enzyme. Proc. Natl. Acad. Sci. USA. 89:3917-3921.

22. Dubois, R.N., J. Awad, J. Morrow, L.J. Roberts, and P.R. Bishop. 1994 Regulation of eicosanoid production and mitogenesis in rat intestinal epithelial cells by transforming growth factor- $\alpha$ and phorbol ester. J. Clin. Invest. 93:493498.

23. Meade, E.A., W.L. Smith, and D.L. Dewitt. 1993. Differential inhibition of prostaglandin endoperoxide synthase (cyclooxygenase) isozymes by aspirin and other non-steroidal anti-inflammatory drugs. J. Biol. Chem. 268:6610-6614.

24. Seibert, K., Y. Zhang, K. Leahy, S. Hauser, J. Masferrer, W. Perkins, L. Lee, and P. Isakson. 1994. Pharmacological and biochemical demonstration of the role of cyclooxygenase 2 in inflammation and pain. Proc. Natl. Acad. Sci. USA. 91:12013-12017.

25. Gierse, J.K., S.D. Hauser, D.P. Creely, C. Koboldt, S.H. Rangwala, P.C. Isakson, and K. Seibert. 1995. Expression and selective inhibition of the constituative and inducible forms of human cyclo-oxygenase. Biochem. J. 385:479-484.

26. Cohn, S.M., and M.W. Lieberman. 1984. The use of antibodies to 5-bromo2 '-deoxyuridine for the isolation of DNA sequences containing excision-repair sites. J. Biol. Chem. 259:12456-12462.

27. Masferrer, J.L., S.T. Reddy, B.S. Zweifel, K. Seibert, P. Needleman, R.S. Gilbert, and H.R. Herschman. 1995. In vivo glucocorticoids regulate cyclooxygenase-2 but not cyclooxygenase-1 in peritoneal macrophages. J. Pharm. Exp. Therapeutics. 270:1340-1344.

28. Masferrer, J.L., B.S. Zweifel, P.T. Manning, S.D. Hauser, K.M. Leahy, W.G. Smith, P.C. Isakson, and K. Seibert. 1994. Selective inhibition of inducible cyclooxygenase 2 in vivo is antiinflammatory and nonulcerogenic. Proc. Natl. Acad. Sci. USA. 91:3228-3232.

29. Reitz, D.B., J.J. Li, M.B. Norton, E.J. Reinhard, J.T. Collins, G.D. Anderson, S.A. Gregory, C.M. Koboldt, W.E. Perkins, K. Seibert, and P.C. Isakson. 1994. Selective cyclooxygenase inhibitors: novel 1,2-diarylcyclopentenes are potent and orally active Cox-2 inhibitors. J. Med. Chem. 37:38783881.

30. Iseki, S. 1995. Immunocytochemical localization of cyclooxygenase-1 and cyclooxygenase-2 in the rat stomach. Histochem. J. 27:323-328.

31. Langenbach, R., S.G. Morham, H.F. Tiano, C.D. Loftin, B.I. Ghanayem, P.C. Chulada, J.F. Mahler, C.A. Lee, E.H. Goulding, K.D. Kluckman, H.S. Kim, and O. Smithies. 1995. Prostaglandin synthase 1 gene disruption in mice reduces arachidonic acid-induced inflammation and indomethacin-induced gastric ulceration. Cell. 83:483-492.

32. Weichselbaum, R.R., D. Hallahan, Z. Fuks, and D. Kufe. 1994. Radiation induction of immediate early genes: Effectors of the radiation-stress response. Int. J. Radiat. Oncol. Biol. Phys. 30:229-234.

tibody was visualized by immunofluorescence using Texas red-labeled donkey anti-goat $\operatorname{IgG}(B, C$, and $D)$ (red fluorescence). In irradiated mice, Cox-1 immunoreactivity was only present in epithelial cells within regenerative crypts $(A$ and $C)$. The distribution of s-phase cells in this section is shown in $B$. Dual immunolocalization of Cox-1 and $\operatorname{BrdUrd}(C)$ demonstrates that all s-phase cells within the regenerating crypt contain high levels of immunoreactive Cox-1. To control for nonspecific binding of antibody, an adjacent section to the section shown in $A-C$ was incubated with normal rabbit serum in substitution for rabbit anti-mouse Cox-1, and bound antibody was detected using fluorescein-conjugated tyramide signal amplification (green fluorescence) $(D)$. The section was subsequently stained with goat anti-BrdUrd to identify replicating cells within the regenerating crypt (red fluorescence). Note the absence of staining epithelial cells within the regenerative crypt. Slight nonspecific immunofluorescence was often observed at the junction of the muscularis propria with the submucosa. 
33. Witte, L., Z. Fuks, A. Haimovitz-Friedman, I. Vlodavsky, D.S. Goodman, and A. Eldor. 1989. Effects of irradiation on the release of growth factors from cultured bovine, porcine, and human endothelial cells. Cancer Res. 49: 5066-5072.

34. Murakami, M., R. Matsumoto, Y. Urade, K.F. Austen, and J.P. Arm. 1995. cKIT ligand mediates increased expression of cytosolic phospholipase A2, prostaglandin endoperoxide synthase-1, and hematopoietic prostaglandin D2 synthase and increased IgE-dependent Prostaglandin D2 generation in immature mouse mast cells. J. Biol. Chem. 270:3239-3246.

35. Samet, J.M., M.B. Fasano, A.N. Foneth, and F.H. Chilton. 1995. Selective induction of Prostaglandin G/H synthase I by stem cell factor and dexamethasone in mast cells. J. Biol. Chem. 270:8044-8049.
36. Kawaguchi, H., C.C. Pilbeam, G. Gronowicz, C. Abreu, B.S. Fletcher, H.R. Herschman, L.G. Raisz, and M.M. Hurley. 1995. Transcriptional induction of prostaglandin $\mathrm{G} / \mathrm{H}$ synthase- 2 by basic fibroblast growth factor. Am. Soc. Clin. Invest. 96:923-930.

37. Sugimoto, Y., T. Namba, R. Shigemoto, M. Negishi, A. Ichikawa, and S. Narumiya. 1994. Distinct cellular localization of mRNAs for three subtypes of prostaglandin E receptor in kidney. Am. J. Physiol. 823-827.

38. Morham, S.G., R. Langenbach, C.D. Loftin, H.F. Tiano, N. Vouloumanos, J.C. Jennette, J.F. Mahler, K.D. Kluckman, A. Ledford, C.A. Lee, and O. Smithies. 1995. Prostaglandin synthase 2 gene disruption causes severe renal pathology in the mouse. Cell. 83:473-482. 